\title{
İlköğretim Matematik Öğretmeni Adaylarının Somut Materyalleri Tanıma-Kullanma Durumları ve Matematik Öğretiminde Kullanmalarına Yönelik Öz-Yeterlikleri ${ }^{1}$
}

\author{
Pre-service Elementary Mathematics Teachers' Awareness of Ability to Use Concrete \\ Materials and Their Self-Efficacy in the Useage Thereof in Mathematics Education
}

\author{
Tuba AYDOĞDU İSKENDEROĞLU ${ }^{2} \quad$ Yasemin TÜRK $^{3}$ Metin İSKENDEROĞLU ${ }^{4}$
}

\author{
Başvuru Tarihi: 04.02.2016 Yayına Kabul Tarihi:27.09.2016 DOI: 10.21764/efd.29539
}

Özet: $\mathrm{Bu}$ çalışmanın amacı, matematik öğretmeni adaylarının matematik öğretiminde kullanılabilecek somut materyallerden haberdar olma ve öğrenme sürecindeki kullanım seviyelerini belirleme ile bu somut materyalleri kullanmalarına yönelik özyeterliklerini ortaya koymaktır. Ayrıca, öğretmen adaylarının somut materyali tanıma ve kullanma seviyeleri ile öz-yeterlikleri arasında bir ilişki olupolmadığı da araştırılacaktır. Bu amaçla tarama modeli kullanılmış olan bu çalışmada üçüncü sınıfa devam etmekte olan toplam 83 ilköğretim matematik ögretmen adayına "Somut Materyallerin Matematik Öğretiminde Kullanımına Yönelik Öz-Yeterlik Ölçeği” ile bilgi formunun uygulanması sonucunda araştırma verileri elde edilmiştir. Çalışmanın sonucunda, ögrretmen adaylarının somut materyalleri matematik öğretiminde kullanma konusunda kendilerini yeterli buldukları, somut materyalleri genellikle tanıdıkları ancak bu materyalleri genellikle kullanmadıkları anlaşılmıştır. Ayrıca, öğretmen adaylarının somut materyalleri matematik öğretiminde kullanmaya yönelik öz-yeterlikleri ile somut materyalleri tanıma ve kullanmaları arasında çok zayıf, negatif ve anlamlı bir ilişki olduğu sonucuna ulaşılmıştır.

Anahtar sözcükler: İlköğretim, matematik, öğretmen adayı, somut materyal, öz-yeterlik.

\begin{abstract}
The aim of this study is to reveal the level of awareness pre-service mathematics teachers have about the concrete materials which can be used for mathematics education, and the level of utilization of such materials through the learning process. Furthermore the study seeks to assess the self-efficacy of the pre-service teachers regarding the use of such concrete materials. The study will also investigate any potential relationship between the pre-service teachers' level of acquaintance with and use of the concrete materials and their self-efficacy levels. The study adopted the survey model for this purpose, and applied the "Self-Efficacy Scale for the Use of Concrete Materials in Mathematics Education" alongside the information sheet, with a total of 83 pre-service elementary school mathematics teachers enrolled in the third year of their bachelor's degree program. The study revealed that pre-service teachers deemed themselves efficient in terms of the use of concrete materials in mathematics education. On the other hand, they were observed to recognize such concrete materials usually, but usually failed to use such materials. Furthermore, a very weak, negative yet significant relationship was observed between the pre-service teachers' levels of self-efficacy in terms of use of concrete materials in mathematics education, and their acquaintance with and use of concrete materials.
\end{abstract}

Keywords: Elementary education, mathematics, preservice teacher, concrete material, self-efficacy.

\footnotetext{
${ }^{1}$ Bu araş̧ırma "Matematik Öğretmeni Adaylarının Özel Öğretim Yöntemleri Dersinde Materyal Kullanımlarına İlişkin Becerileri" başlıklı 9662 kodlu BAP 03 AR-GE Başlangıç Desteği projesinden yapılmıştır.

${ }^{2}$ Yrd. Doç. Dr. Karadeniz Teknik Üniversitesi Fatih Eğitim Fakültesi İlköğretim Bölümü Sınıf Eğitimi tiskenderoglu@ktu.edu.tr

${ }^{3}$ Okt. Karadeniz Teknik Üniversitesi Fatih Eğitim Fakültesi İlköğretim Bölümü Sınıf Eğitimi sengun_y@ @otmail.com

${ }^{4}$ Uzm. Karadeniz Teknik Üniversitesi Fatih Eğitim Fakültesi Bilgisayar ve Öğretim Teknolojileri Eğitimi Bölümü miskenderoglu@ktu.edu.tr
} 


\section{Giriş}

İlköğretim matematik eğitiminde somut materyal kullanımının önemi ilköğretim öğrencilerinin gelişim özellikleri ile doğrudan ilgilidir. Gelişimsel olarak öğrenmenin somutlaştırılması bu öğrenciler için oldukça önemlidir. Piaget'e göre ilköğretim çağı çocuklarına kazandırılmak istenen davranışlar için hazırlanmış bir dersin içeriğinin, bu çocukların beş duyu organına da hitap edecek şekilde desteklenmiş olması yani somutlaştırılması gereklidir. Skemp'de (1987) çocukların somut nesneler ile girdikleri etkileşimlerin soyut anlamalarını desteklediğini söylemiştir. Matematik soyutlama bilimidir ve matematiğin içeriğinde birçok soyut kavram bulunmaktadır (Altun, 2002). Bu tanım incelendiğinde "soyutlama" kavramının ön plana çıktığı görülmektedir. Soyutlamanın ise ilköğretim öğrencileri için kolay olmayacağı açıktır. İlköğretim öğrencilerinin matematik içerisinde yer alan kavramları somut tecrübelerinden yararlanarak öğrenmeleri, yalnızca matematik öğrenmelerine değil matematiği içselleştirmelerine ve soyutlamayı daha kolay yapabilmelerine zemin hazırlayacaktır.

Milli Eğitim Bakanlığı tarafından yapılandırmacı eğitim felsefesi benimsenerek oluşturulan ve 2005 yılından itibaren uygulamada olan yeni matematik öğretim programında somut materyal kullanımına vurgu yapılmaktadır. $\mathrm{Bu}$ matematik öğretim programının vizyonu incelendiğinde, matematikle ilgili kavramların doğası gereği soyut nitelikte olması, buna karşın çocukların gelişim özellikleri incelendiğinde bu soyut kavramların onlar tarafından algılanmasının zor olması, matematikle ilgili kavramların öğretiminin somut materyallerle desteklenmesi gerekliliği başlıkları vurgulanmaktadır. Program, öğrencilerin matematik yapma sürecinde etkin katılımcı olması gerektiğini esas alarak, ilköğretim çağındaki öğrencilerin çevreleriyle, somut nesnelerle ve akranlarıyla etkileşimlerinden kendi düşüncelerini oluşturacaklarını dile getirmektedir (Milli Eğitim Bakanlığı, 2013). Program, somut modelli öğrenmeye dayalı etkinlikler ile öğrencinin kendisinin keşfederek ve anlayarak öğrenmesini esas almaktadır (Bulut, 2004).

Somut materyaller, soyut matematik kavramlarını somutlaştıran nesneler, resimler gibi özel olarak bu amaç için oluşturulmuş matematik araç-gereçlerini ve gerçek hayattan nesneleri içerir (Van de Walle, 2007). Somut materyaller dokunulabilen ve hareket ettirilebilen objeler olarak kabul edilirler (Haciömeroğlu ve Apaydın, 2009). Bu materyaller, matematiksel kavramların daha açık ve daha somut bir şekilde anlaşılmasına yardımcı olan nesnelerdir (Moyer, 2001). Somut materyal için yapılan bu tanımlar, literatürdeki çalışmalar ve ilköğretim öğrenci özellikleri incelendiğinde öğretimde somut materyal kullanımının gerekli olduğu anlaşılmaktadır. İlköğretim çağı öğrencileri soyut kavramları anlayamazlar ve bu nedenle de soyut kavram ve deneyimlerin somut yollarla açıklanması gerekir. İlköğretim öğrencileri bilgilerin somut modellerle temsil edildiği öğrenme ortamlarında daha anlamlı öğrenirler (Clements ve McMillen, 1996). Somut materyal kullanımı, matematiksel kavramların somut olarak ifade edilmelerini sağlayarak öğrencilerin kavramları daha kolay anlamalarına yardımcı olur (Bulut, Çölekoğlu, Seçil, Yıldırım ve Yıldız, 2002). Ayrıca somut materyaller, öğrencilere akranlarıyla birlikte görüş açılarını genişletme firsatları sunarlar (Brecht, 2000; Kamii ve Lewis,1990; Özdemir, 2008; Williams ve Kamii, 1986). Çünkü gözle gördükleri ve elle tuttukları gerçek eşya ve modeller onlar için daha anlamlıdır (Yolcu ve Kurtuluş, 2010).Bu somut yolların kullanılabilmesi ise, öğretmenlerin bu konuda sahip oldukları bilgiye, yeterliliğe ve bu konudaki inançlarına bağlıdır. Buna ek olarak NCTM Ulusal Matematik Öğretmenleri Konseyi’nin (2000) standartları incelendiğinde, öğrencilerin kendi öğrenme süreçlerinde aktif rol alabilmeleri için öğretmenler tarafından matematik araçlarının kullanılması gerektiği vurgulanmaktadır. Bununla birlikte, öğretmen gerekli kullanma becerisine sahip değilse veya bunların yararlı olduğuna inanmıyorsa, bu araç gereçleri kullanmak istemeyecektir (Yalın, 1997). Bu nedenle geleceğin öğretmenleri olan öğretmen adaylarının da somut materyalleri bilmeleri ve etkili biçimde kullanabilmeleri önemlidir. 
$\mathrm{Bu}$ alanda yapılan farklı çalışmalar da, somut materyal kullanımının öğrenci başarısını ve tutumlarını olumlu yönde arttırdığını ortaya koymaktadır (Bozkurt ve Polat, 2011; Briars, 1990; Fuson ve Kelly, 2006; Gürbüz, 2007; Kıyıcı, Erdoğmuş ve Sevinç, 2007; Özdemir, 2008; Thompson, 1994; Ünal ve İpek, 2009;). Bu çalışmaların sonuçları incelendiğinde ortak kanı somut materyal kullanımının öğrencilerin başarılarını $\operatorname{arttırdığı~ve~tutumlarını~olumlu~yönde~etkilediği~yönündedir.~Kelly~(2006)~tarafından~yapılmış~olan~}$ çalışmasında, matematik öğretiminde somut nesne kullanımının özellikle ilkokul yıllarında başlamasının öğrencilerin öğrenmeleri ve problem çözme becerileri yönünden çok faydalı olacağı sonucuna varılmıştır. Ayrıca, bu çalışmada matematik öğretiminde özellikle de ilkokul yıllarında somut nesne kullanımının öğrencilerin ilerleyen yıllardaki öğrenmelerini ve iş hayatlarını da olumlu yönde etkileyeceği açıklanmıştır. Kıyıcı, Erdoğmuş ve Sevinç (2007) tarafından yapılmış olan bir başka çalışmada ise, öğretmen adaylarının somut materyallerin öğrencilerin psiko-motor becerilerini geliştirdiğini, öğrenme süresini kısalttığını, öğrenilmesi çok zor karmaşı bilgilerde öğrencilerin öğrenmesini kolaylaştırdığını düşündükleri ortaya koyulmuştur.

Ulaşılan bu bilgiler 1şı̆̆ında, bu çalışmada ilköğretim matematik öğretmeni adaylarının matematik öğretiminde kullanılabilecek somut materyallerden haberdar olma ve öğrenme sürecindeki kullanım seviyelerinin belirlenmesi ile bu somut materyal kullanımına yönelik adayların öz-yeterliklerinin ortaya koyulması amaçlanmıştır. Ayrıca, öğretmen adaylarının somut materyalleri tanıma ve kullanma seviyeleri ile öz-yeterlikleri arasında bir ilişki olup-olmadığı da araştırılacaktır.

\section{Yöntem}

$\mathrm{Bu}$ çalışmada, niceliksel araştırma desenlerinden tarama modeli kullanılmıştır. Tarama modelleri, geçmişte veya şimdide var olan bir durumu var olduğu haliyle betimlemeyi amaçlar (Karasar, 2009). Bu çalışmada da ilköğretim matematik öğretmeni adaylarının matematik öğretiminde kullanılabilecek somut materyallerden ne kadar haberdar oldukları, öğrenme sürecinde ne kadar kullandıkları ve somut materyal kullanımına yönelik öz-yeterlikleri betimlencektir. Bu süreçte öğretmen adaylarının şimdiki var olan durumları ortaya çıkarılmaya çalışılacaktır.

\section{Çalışma Grubu}

Çalışmaya, Doğu Karadeniz Bölgesi’ndeki bir devlet üniversitesinin Eğitim Fakültesinde öğrenim görmekte olan İlköğretim Matematik öğretmeni adayları katılmıştır. Çalışma grubu belirlenirken amaçlı örnekleme yöntemi kullanılmıştır. Bu örnekleme türünde araştırmacı kendi yargısını kullanarak araştırmanın amacına en uygun olan kişileri örnekleme alır (Balc1, 2001; s: 102). Buna bağlı olarak çalışmaya Öğretim Teknolojileri ve Materyal Tasarımı dersi ile Özel Öğretim Yöntemleri 1 dersini almış ve üçüncü sınıfa devam etmekte olan toplam 88 ilköğretim matematik öğretmeni adayı katılmıştır. Fakat 5 öğretmen adayından elde edilen veriler eksik olduğundan dolayı çalışmaya dâhil edilmemiştir.

\section{Veri Toplama Aracı}

Öğretmen adaylarının somut materyal kullanımına yönelik öz-yeterliklerini ölçmek için Enochs, Smith ve Huinker (2000) tarafından geliştirilmiş ve Bakkaloğlu (2007) tarafından Türkçe'ye uyarlanmış olan "Somut Materyallerin Matematik Öğretiminde Kullanımına Yönelik Öz-Yeterlik Ölçeği” kullanılmıştır. İlköğretim matematik öğretmeni adaylarının somut materyal kullanımıyla ilgili öz-yeterliklerini ölçmeye yönelik olarak hazırlanmış olan bu ölçekte toplam 16 madde bulunmaktadır. Ölçek Hiç Katılmıyorum (1), Katılmıyorum (2), Kararsızım (3), Katılıyorum (4) ve Tamamen Katılıyorum (5) şeklinde 5'li Likert tipi bir derecelendirme ölçeğidir. Ayrıca ölçekte iki faktör yer almaktadır. Bunlardan birincisi "Materyal kullanımına yönelik 
öğretim yeterliliği (öz-yeterlik)" faktörüne ait olup, ölçekte yer alan 1, 2, 3, 5, 6, 7, 12, 15 ve 16. maddelerini kapsamaktadır. Ölçekte yer alan 4, 8, 9, 10, 11, 13, 14. maddeler de "Materyal kullanımından beklentiler (sonuç beklentisi)" faktörüne aittir. Bununla birlikte ölçekte yer alan 1, 2, 3, 4, 8, 12 ve 14. maddeler olumsuz ifade içermektedir. Materyal kullanımına yönelik öğretim yeterliliği alt başlı̆̆ının güvenirlik katsayısı Bakkaloğlu (2007) tarafından 0.81 olarak hesaplanırken materyal kullanımından beklentiler alt başlığının güvenirlik katsayısı 0.79 olarak hesaplanmıştır.

Bu çalışmada ayrıca, ilköğretim matematik öğretmeni adaylarının somut materyallerden haberdar olma ve öğrenim sürecinde kullanabilme düzeylerinin tespit edilebilmesi amaciyla adayların somut materyaller konusundaki bilgi ve kullanımlarına ilişkin iki sorudan oluşan bilgi formundan yararlanılmıştır. Bakkaloğlu (2007) tarafından hazırlanmış olan formda liste biçiminde somut materyallerin isimleri ve bu iki soru yer almaktadır. Bunlardan birinci soru, "Somut materyaller hakkında bilginiz var mı?" ve ikinci soru "Somut materyalleri matematik öğretiminde/öğreniminde kullandınız mı?” şeklindedir. Soruların yanıtları evet-hayır niteliğinde olup öğretmen adaylarından her bir somut materyalin karşısında bırakılan boşluğa yanıtlarını işaretlemeleri istenmiştir.

Verilerin Toplanmas1

Veriler 2013-2014 öğretim yılı bahar yarıyılında dönem başında “Özel Öğretim Yöntemleri 2" dersinde toplanmıştır. Bir derste öğretmen adaylarına öncelikle çalışmada kullanılacak olan iki sorunun yer aldığı bilgi formu uygulanmıştır. Katılımcılar tarafından bu formun tamamlanması yaklaşık 15-20 dakika sürmüştür. Ardından çalışmaya katılan öğretmen adaylarına "Somut Materyallerin Matematik Öğretiminde Kullanımına Yönelik Öz-Yeterlik Ölçeği” dağıtılmış ve ölçekte yer alan maddeleri yanıtlamaları yaklaşık 10 dakikada sürmüştür.

\section{Verilerin Analizi}

Araştırmada kullanılan bilgi formunda yer alan soruların yanıtları evet-hayır niteliğinde olup ilköğretim matematik öğretmeni adaylarının bu sorulara verdikleri yanıtların analizi sürecinde betimsel analiz yapılmıştır. Betimsel analiz sonucunda verilen yanıtların frekans (f) ve yüzdeleri (\%) belirlenerek tablolar halinde sunulmuştur.

Araştırmada kullanılan ölçekte ise iki faktörlü bir yapı bulunmaktadır ve her alt ölçekten ayrı ayrı puan elde edilebilmektedir. Likert türü her maddenin puanlaması, 5,4,3,2,1 olarak yapılmıştır. Bunun yanı sıra olumsuz görüş içeren 7 madde ters çevrilerek analiz edilmiştir. Aralıkların eşit olduğu varsayılarak puan aralı̆̆ katsayısı 0.80 olarak bulunmuştur. Puan Aralığı $=($ En Yüksek Değer-En Düşük Değer $) / 5=4 / 5=0.80$ 'dir. Öğretmen adaylarının her bir maddeden aldıkları puanların ortalamalarını değerlendirme aralığı yorumlanırken; "1.00-1.80" arasındaki ortalamaların "hiç katılmıyorum"; "1.81-2.60" arasında bulunanların "kat1lmiyorum"; "2.61-3.40" arasındakilerin "kararsızım"; "3.41-4.20" arasındakilerin "kat1lyorum" ve “4.21-5.00" arasındakilerin ise "tamamen katılıyorum" derecesinde değer taşıdıkları kabul edilmiştir.

Daha sonra matematik öğretmeni adaylarının somut materyal kullanımıyla ilgili öz-yeterlikleri ve somut materyaller hakkındaki bilgileri ile somut materyalleri kullanma durumları arasındaki ilişkiyi bulmak için korelasyon analizi yapılmıştır. 


\section{Bulgular ve Yorumlar}

$\mathrm{Bu}$ bölümde, ilköğretim matematik öğretmeni adaylarının somut materyallerden haberdar olma ve öğrenim sürecindeki kullanabilme düzeylerini tespit etmek amaciyla gerçekleştirilen analizlere ve bu analizlere ilişkin yapılan yorumlara yer verilmiştir. Ayrıca öğretmen adaylarının matematik öğretiminde somut materyal kullanımı konusundaki öz-yeterlikleri belirlenerek öz-yeterlikleri ile somut materyali tanıma ve kullanma arasındaki ilişkiye bakılmıştır. Tablo 1'de ilköğretim matematik öğretmeni adaylarının somut materyallerden haberdar olma durumlarının analiz sonuçlarına yer verilmiştir.

Tablo 1. İlköğretim Matematik Öğretmeni Adaylarının Somut Materyallerden Haberdar Olma Düzeyleri

\begin{tabular}{|c|c|c|c|c|}
\hline \multirow{3}{*}{ Somut Materyaller } & \multicolumn{4}{|c|}{ Somut materyal hakkında bilginiz var mı? } \\
\hline & \multicolumn{2}{|c|}{ Evet } & \multicolumn{2}{|c|}{ Hayır } \\
\hline & $\mathrm{f}$ & $\%$ & $\mathrm{f}$ & $\%$ \\
\hline 1. Onluk Taban Blokları & 46 & 55,42 & 37 & 44,58 \\
\hline 2.Birim Küpler & 77 & 92.77 & 6 & 7.23 \\
\hline 3.Geometri Tahtas1 & 52 & 62.65 & 31 & 37.35 \\
\hline 4.Örüntü Blokları & 25 & 30.12 & 58 & 69.88 \\
\hline 5.Simetri Aynasi & 67 & 80.72 & 16 & 19.28 \\
\hline 6.Tangram & 56 & 67.47 & 27 & 32.53 \\
\hline 7.Kesir Çubukları & 47 & 56.63 & 36 & 43.37 \\
\hline 8.Geometri Şeritleri & 32 & 38.55 & 51 & 61.45 \\
\hline 9. Onluk Kart & 24 & 28.92 & 59 & 71.08 \\
\hline 10.Geometrik Cisimler & 76 & 91.57 & 7 & 8.43 \\
\hline 11.İzometrik Kâğıt & 57 & 68.67 & 26 & 31.33 \\
\hline 12.Noktalı Kâğıt & 56 & 67.47 & 27 & 32.53 \\
\hline 13.Yüzlük Kart & 23 & 27.71 & 60 & 72.29 \\
\hline 14.Yüzlük Tablo & 25 & 30.12 & 58 & 69.88 \\
\hline 15.Șeffaf Kesir Kartları & 19 & 22.89 & 64 & 77.11 \\
\hline 16.Çok Kareliler Takımı & 18 & 21.69 & 65 & 78.31 \\
\hline 17.Çok Küplüler Takımı & 17 & 20.48 & 66 & 79.52 \\
\hline 18.Cebir Karoları & 13 & 15.66 & 70 & 84.34 \\
\hline 19.Hacimler Takımı & 33 & 39.76 & 50 & 60.24 \\
\hline 20.Şeffaf Sayma Pulları & 33 & 39.76 & 50 & 60.24 \\
\hline 21.Saat & 80 & 96.39 & 3 & 33.61 \\
\hline 22.Terazi & 77 & 92.77 & 6 & 7.23 \\
\hline 23.Geometrik Cisimlerin Açınımları & 78 & 93.98 & 5 & 6.02 \\
\hline 24.Geometrik Cisimlerin Kesit-Arakesitleri & 64 & 77.11 & 19 & 22.89 \\
\hline 25.Sayı Çubukları & 61 & 73.49 & 22 & 26.51 \\
\hline 26.Üçgensel Kâğ & 47 & 56.63 & 36 & 43.37 \\
\hline 27.Kareli Kâğıt & 69 & 83.13 & 14 & 16.87 \\
\hline 28.Çizgisiz Kâğıt/Eliși Kâğıdd1/Karton & 79 & 95.18 & 4 & 4.82 \\
\hline
\end{tabular}

Tablo 1 incelendiğinde çalışmaya katılan öğretmen adaylarının somut materyallerin çoğu hakkında bilgi sahibi oldukları anlaşılmaktadır. Çalışmadan elde edilen verilere bakıldığında ilköğretim matematik öğretmeni adaylarının en çok (\%96.39) bilgi sahibi oldukları somut materyal saattir. Ardından, ilköğretim matematik öğretmeni adaylarının en çok hakkında bilgi sahibi oldukları somut materyaller \%95.18 ile çizgisiz kâğıt/karton/elişi kâğıdı, \%93.98 ile geometrik cisimlerin açınımları, \%92,77 ile terazi, \%92.77 ile birim küpler ve \%91.57 ile geometrik cisimlerdir. Öğretmen adaylarının en az (\%15.66) bilgi sahibi oldukları somut materyalin ise cebir karoları olduğu görülmüştür. Cebir karolarından sonra en az bilgi sahibi olunan somut materyaller ise \%20.48 ile çok küplüler takımı, \%21.69 ile çok kareliler takımı ve \%22.89 ile şeffaf kesir kartlarıdır. 
Aşağıda yer alan Tablo 2'de, ilköğretim matematik öğretmeni adaylarının somut materyalleri kullanma düzeyleri yer almaktadır.

Tablo 2. İlköğretim Matematik Öğretmeni Adaylarının Somut Materyalleri Kullanma Düzeyleri

\begin{tabular}{|c|c|c|c|c|}
\hline \multirow{3}{*}{ Somut Materyaller } & \multicolumn{4}{|c|}{ Somut materyali kullandınız mı? } \\
\hline & \multicolumn{2}{|l|}{ Evet } & \multicolumn{2}{|c|}{ Hayır } \\
\hline & $\mathrm{f}$ & $\%$ & $\mathrm{f}$ & $\%$ \\
\hline 1. Onluk Taban Blokları & 32 & 38.55 & 51 & 61.45 \\
\hline 2.Birim Küpler & 65 & 78.31 & 18 & 21.69 \\
\hline 3.Geometri Tahtas1 & 33 & 39.76 & 50 & 60.24 \\
\hline 4.Örüntü Blokları & 14 & 16.87 & 69 & 83.13 \\
\hline 5.Simetri Aynası & 44 & 53.01 & 39 & 46.99 \\
\hline 6.Tangram & 41 & 49.40 & 42 & 50.60 \\
\hline 7.Kesir Çubukları & 34 & 40.96 & 49 & 59.04 \\
\hline 8.Geometri Şeritleri & 16 & 19.28 & 67 & 80.72 \\
\hline 9.Onluk Kart & 11 & 13.25 & 72 & 86.75 \\
\hline 10.Geometrik Cisimler & 72 & 86.75 & 11 & 13.25 \\
\hline 11.İzometrik Kâğıt & 43 & 51.81 & 40 & 48.19 \\
\hline 12.Noktalı Kâğgtt & 45 & 54.22 & 38 & 45.78 \\
\hline 13.Yüzlük Kart & 11 & 13.25 & 72 & 86.75 \\
\hline 14.Yüzlük Tablo & 18 & 21.69 & 65 & 78.31 \\
\hline 15.Şeffaf Kesir Kartları & 10 & 12.05 & 73 & 87.95 \\
\hline 16.Çok Kareliler Takımı & 12 & 14.46 & 71 & 85.54 \\
\hline 17.Çok Küplüler Takımı & 12 & 14.46 & 71 & 85.54 \\
\hline 18.Cebir Karoları & 5 & 6.02 & 78 & 93.98 \\
\hline 19.Hacimler Takımı & 24 & 28.92 & 59 & 71.08 \\
\hline 20.Şeffaf Sayma Pulları & 21 & 25.30 & 62 & 74.70 \\
\hline 21.Saat & 76 & 91.57 & 7 & 843 \\
\hline 22.Terazi & 74 & 89.16 & 9 & 10.84 \\
\hline 23.Geometrik Cisimlerin Açınımları & 72 & 86.75 & 11 & 13.25 \\
\hline 24.Geometrik Cisimlerin Kesit Arakesitleri & 56 & 67.47 & 27 & 32.53 \\
\hline 25.Sayı Çubukları & 52 & 62.65 & 31 & 37.35 \\
\hline 26.Üçgensel Kâğ & 36 & 43.37 & 47 & 56.63 \\
\hline 27.Kareli Kâğıt & 65 & 78.31 & 18 & 21.69 \\
\hline 28.Cizgisiz Kâğıt/Eliși Kâğıd1/Karton & 72 & 86.75 & 11 & 13.25 \\
\hline
\end{tabular}

Tablo 2 incelendiğinde ilköğretim matematik öğretmeni adaylarının en çok (\%91.57) kullandıkları somut materyalin saat olduğu görülmektedir. Saatten sonra en çok kullanılan somut materyal \%89.16 ile terazi, \%86.75 ile geometrik cisimlerin açınımları, \%86.75 ile çizgisiz kâğıt/karton/elişi kâğıdı ve \%86.75 ile geometrik cisimlerdir. Bunun yanı sıra öğretmen adaylarının en az (\%6.02) kullandıkları somut materyal de cebir karoları olmuştur. Cebir karolarından sonra en az kullanılan somut materyaller ise \%12.05 ile şeffaf kesir kartları, \%13.25 ile yüzlük kart ve \%13.25 ile onluk kartlardır.

Aşağıda yer alan tabloda ise, ilköğretim matematik öğretmeni adaylarının somut materyallerden haberdar olma ve kullanma düzeyleri yer almaktadır (Tablo 3). 
Tablo 3. İlköğretim Matematik Öğretmeni Adaylarının Somut Materyallerden Haberdar Olma ve Kullanma Düzeyleri

\begin{tabular}{|c|c|c|c|c|}
\hline \multirow[b]{3}{*}{ Somut materyaller } & \multicolumn{2}{|c|}{$\begin{array}{l}\text { Somut materyal hakkında } \\
\text { bilginiz var mı? }\end{array}$} & \multicolumn{2}{|c|}{$\begin{array}{l}\text { Somut } \\
\text { kullandınız mı? }\end{array}$} \\
\hline & \multicolumn{2}{|l|}{ Evet } & \multicolumn{2}{|c|}{ Evet } \\
\hline & $\mathrm{f}$ & $\%$ & $\mathrm{f}$ & $\%$ \\
\hline 1. Onluk Taban Blokları & 46 & 55.42 & 32 & 38.55 \\
\hline 2.Birim Küpler & 77 & 92.77 & 65 & 78.31 \\
\hline 3.Geometri Tahtası & 52 & 62.65 & 33 & 39.76 \\
\hline 4.Örüntü Blokları & 25 & 30.12 & 14 & 16.87 \\
\hline 5.Simetri Aynas1 & 67 & 80.72 & 44 & 53.01 \\
\hline 6.Tangram & 56 & 67.47 & 41 & 49.40 \\
\hline 7.Kesir Çubukları & 47 & 56.63 & 34 & 40.96 \\
\hline 8.Geometri Şeritleri & 32 & 38.55 & 16 & 19.28 \\
\hline 9.Onluk Kart & 24 & 28.92 & 11 & 13.25 \\
\hline 10.Geometrik Cisimler & 76 & 91.57 & 72 & 86.75 \\
\hline 11.İzometrik Kâğıt & 57 & 68.67 & 43 & 51.81 \\
\hline 12.Noktalı Kâğıtt & 56 & 67.47 & 45 & 54.22 \\
\hline 13.Yüzlük Kart & 23 & 27.71 & 11 & $13 ., 2$ \\
\hline 14.Yüzlük Tablo & 25 & 30.12 & 18 & 21.69 \\
\hline 15.Şeffaf Kesir Kartları & 19 & 22.89 & 10 & 12.05 \\
\hline 16.Çok Kareliler Takımı & 18 & 21.69 & 12 & 14.46 \\
\hline 17.Çok Küplüler Takımı & 17 & 20.48 & 12 & 14.46 \\
\hline 18.Cebir Karolar1 & 13 & 15.66 & 5 & 6.02 \\
\hline 19.Hacimler Takımı & 33 & 39.76 & 24 & 28.92 \\
\hline 20.Şeffaf Sayma Pulları & 33 & 39.76 & 21 & 25.30 \\
\hline 21.Saat & 80 & 96.39 & 76 & 91.57 \\
\hline 22.Terazi & 77 & 92.77 & 74 & 89.16 \\
\hline 23.Geometrik Cisimlerin Açınımları & 78 & 93.98 & 72 & 86.75 \\
\hline 24.Geometrik Cisimlerin Kesit-Arakesitleri & 64 & 77.11 & 56 & 67.47 \\
\hline 25.Sayı Çubukları & 61 & 73.49 & 52 & 62.65 \\
\hline 26.Üçgensel Kâğıt & 47 & 56.63 & 36 & 43.37 \\
\hline 27.Kareli Kâğıt & 69 & 83.13 & 65 & 78.31 \\
\hline 28.Çizgisiz Kâğıt/Elişi Kâğıd1/Karton & 79 & 9518 & 72 & 86.75 \\
\hline
\end{tabular}

Tablo 3'de incelendiğinde, ilköğretim matematik ögretmeni adaylarının somut materyalleri tanıma ve kullanma yüzdelerinde farklılık olduğu görülmektedir. Ayrıca, somut materyallerin tamamında öğretmen adaylarının somut materyali kullanma yüzdesi tanıma yüzdesinden daha düşüktür.

İlköğretim matematik öğretmeni adaylarının "Somut Materyallerin Matematik Öğretiminde Kullanımına Yönelik Öz-Yeterlik Ölçeği” ndeki maddelere yönelik verdikleri yanıtların ortalaması (3.72) katılıyorum düzeyindedir. Bu durum da, gösteriyor ki ilköğretim matematik öğretmeni adaylarının somut materyalleri matematik öğretiminde kullanma konusunda öz-yeterlikleri ve kullandıklarında da sonuç alacaklarına dair düşüncelerinin olumlu olduğuna işaret etmektedir. Bu ölçekte iki farklı faktör yer almaktadır. Tablo 4'de her bir madde için ilköğretim matematik öğretmeni adaylarının somut materyallerin matematik öğretiminde kullanımına yönelik öz-yeterliklerinin ortalamaları yer almaktadır. 
Tablo 4. Illköğretim Matematik Öğretmeni Adaylarının Somut Materyallerin Matematik Öğretiminde Kullanımına Yönelik Öz-Yeterlikleri

\begin{tabular}{|c|c|c|}
\hline No & İfadeler & Ortalama \\
\hline 1. & Somut materyallerle ders işlerken sınıfı kontrol edemeyeceğimi düşünüyorum. & 3.66 \\
\hline 2. & $\begin{array}{l}\text { Eğer somut materyal kullanarak işlediğim dersler amacına ulaşmazsa nedenini } \\
\text { kendimde ararım. }\end{array}$ & 2.69 \\
\hline 3. & $\begin{array}{l}\text { Matematik öğretiminde somut materyal kullanımı ile ilgili bilgiye yeterince sahip } \\
\text { değilim. }\end{array}$ & 3.29 \\
\hline 5. & $\begin{array}{l}\text { Dersi somut materyallerle işlemek için gerekli becerilere sahip olacağımı } \\
\text { düşünüyorum. }\end{array}$ & 3.72 \\
\hline 6. & $\begin{array}{l}\text { Somut materyaller hakkında öğrencilerin sorularını cevaplayabileceğimi } \\
\text { düşünüyorum. }\end{array}$ & 3.88 \\
\hline 7. & Somut materyalleri ders içinde etkili biçimde kullanabileceğimi düşünüyorum. & 3.77 \\
\hline 12. & $\begin{array}{l}\text { Derste somut materyallerin nasıl kullanılacağını öğrencilere anlatmakta zorluk } \\
\text { çekeceğim. }\end{array}$ & 3.53 \\
\hline 15. & Dersi somut materyal kullanarak işlemede yeterli olacağımı düşünüyorum. & 3.53 \\
\hline 16. & Kendim de materyal geliştirebileceğimi düşünüyorum. & 3.87 \\
\hline
\end{tabular}

Çalışmada kullanılan "Somut Materyallerin Matematik Öğretiminde Kullanımına Yönelik Öz-Yeterlik Ölçeği” nde yer alan öz-yeterlik faktörüne ait maddelere öğretmen adaylarının verdikleri yanıtların ortalaması 3.55 'dir. $\mathrm{Bu}$ da, bu öğretmen adaylarının "katılıyorum" düzeyinde olduklarını ve kendilerini somut materyal kullanma konusunda yeterli bulduklarını göstermektedir. Başka bir ifadeyle, bu öğretmen adayları kendilerini en çok somut materyaller hakkında öğrencilerin sorularını cevaplayabilme konusunda yeterli gördüklerine işaret etmektedir.

Araştırmada kullanılan bu ölçekte yer alan diğer faktör ise sonuç beklentisidir ve Tablo 5'de bu faktöre ait bulgular yer almaktadır.

Tablo 5. Illköğretim Matematik Öğretmeni Adaylarının Somut Materyallerin Matematik Öğretiminde Kullanımında Sonuç Beklentileri

\begin{tabular}{lll}
\hline No & İfadeler & Ortalama \\
\hline 4. & Somut materyallerle dersimi işlerken tedirgin olacağımı düşünüyorum. & 3.34 \\
8. & $\begin{array}{l}\text { Somut materyal kullanımı ögrencilerin kafasını karıştıracaktır. } \\
\text { 9. }\end{array}$ & Matematik öğretiminde materyal kullanımı öğrencinin başarısına büyük ölçüde yardımcı \\
& $\begin{array}{l}\text { olur. } \\
\text { 10. }\end{array}$ & $\begin{array}{l}\text { Eğer bir öğrenci matematik dersinde daha başarılı ise bunun nedeni büyük olasılıkla o } \\
\text { dersin somut materyallerle işlenmesidir. }\end{array}$ \\
11. & Öğrencilerin matematik bilgilerindeki yetersizliklerin üstesinden somut materyal kullanımı & 4.07 \\
& ile gelinebilir. & \\
13. & Derslerin zengin somut materyal ile desteklenmesi öğrencinin başarısını doğrudan etkiler. & 4.11 \\
14. & Matematikte somut materyal kullanmak zaman kaybıdır. & 4.06 \\
\hline
\end{tabular}

$\mathrm{Bu}$ ölçekte yer alan sonuç beklentisi faktörüne ait maddelere öğretmen adaylarının verdikleri yanıtların ortalamaları 3.94 olarak hesaplanmıştır. Bu durum da, öğretmen adaylarının "katıllyorum" düzeyinde olduklarını ve kullandıklarında da sonuçların olumlu olacağını düşündüklerini göstermektedir. Ayrıca, öğretmen adayları matematik öğretiminde materyal kullanımının öğrencinin başarısına büyük ölçüde yardımcı olacağını düşünmektedirler

İlköğretim matematik öğretmeni adaylarının somut materyalleri matematik öğretiminde kullanmaya yönelik öz-yeterlikleri ile somut materyalleri tanımaları arasında ilişki olup olmadığını ortaya koymaya yönelik olarak gerçekleştirilmiş olan korelasyon analizi sonuçlarına aşağıda yer alan Tablo 6'da yer verilmiştir. 
Tablo 6. İlköğretim Matematik Öğretmeni Adaylarının Somut Materyalleri Matematik Öğretiminde Kullanmaya Yönelik Öz-Yeterlikleri ile Somut Materyalleri Tanımaları Arasındaki İlişki

\begin{tabular}{lllll}
\hline & Değişken & $\mathrm{N}$ & $\mathrm{r}$ & $\mathrm{p}$ \\
\hline $\begin{array}{l}\text { Spearman } \\
\text { Brown }\end{array}$ & Ölçek & 83 & -0.101 & 0.000 \\
& Tanıma & & & \\
\hline
\end{tabular}

Tablo 6 incelendiğinde, ilköğretim matematik öğretmeni adaylarının somut materyalleri matematik öğretiminde kullanmaya yönelik öz-yeterlikleri ile somut materyalleri tanımaları arasında yapılan korelasyon analizi sonucunda aralarında çok zayıf, negatif ve anlamlı bir ilişki bulunmuştur $(\mathrm{r}=-0.101, \mathrm{p}<.01)$. Buna göre öğretmen adaylarının öz-yeterlikleri artarken somut materyalleri tanıma durumları azalmaktadır. Determinasyon katsayısı $\left(\mathrm{r}^{2}=0.01\right)$ dikkate alındığında, öz-yeterlikteki toplam varyansın (değişkenliğin) \%1'inin somut materyalleri tanımadan kaynaklandığı söylenebilir.

Çalışmaya katılan matematik öğretmeni adaylarının somut materyalleri matematik öğretiminde kullanmaya yönelik öz-yeterlikleri ile somut materyalleri kullanmaları arasındaki ilişkiye ait veriler aşağıda yer alan Tablo 7'de sunulmaktadır.

Tablo 7. Illkögrretim Matematik Öğretmeni Adaylarının Somut Materyalleri Matematik Öğretiminde Kullanmaya Yönelik Öz-Yeterlikleri ile Somut Materyalleri Kullanmaları Arasındaki İlişki

\begin{tabular}{lllll}
\hline & Değişken & $\mathrm{N}$ & $\mathrm{r}$ & $\mathrm{p}$ \\
\hline $\begin{array}{l}\text { Spearman } \\
\text { Brown }\end{array}$ & Ölçek & 83 & -0.156 & 0.000 \\
\hline
\end{tabular}

Tablo 7 incelendiğinde, öğretmen adaylarının somut materyalleri matematik öğretiminde kullanmaya yönelik öz-yeterlikleri ile somut materyalleri kullanmaları arasında yapılan korelasyon analizi sonucunda aralarında çok zayıf, negatif ve anlamlı bir ilişki bulunmuştur ( $\mathrm{r}=-0.156, \mathrm{p}<.01)$. Buna göre öğretmen adaylarının özyeterlikleri artarken somut materyalleri kullanma durumları azalmaktadır. Determinasyon katsayısı $\left(\mathrm{r}^{2}=0.02\right)$ dikkate alındığında, öz-yeterlikteki toplam varyansın (değişkenliğin) \%2'sinin somut materyalleri kullanmadan kaynaklandığg söylenebilir.

\section{Tartışma, Sonuç ve Öneriler}

$\mathrm{Bu}$ çalışmadan elde edilen veriler incelendiğinde öğretmen adaylarının somut materyallerin çoğu hakkında bilgi sahibi oldukları görülmektedir. İlköğretim matematik öğretmeni adaylarının en çok bilgi sahibi oldukları somut materyal saat iken bunu çizgisiz kâğıt/karton/elişi kâğıdı, geometrik cisimlerin açınımları, terazi, birim küpler ve geometrik cisimler takip etmiştir. Bu somut materyallerin bilinmesinin nedeni daha önceki öğrenim hayatlarında karşılaşmış olmaları olabilir. Ulaşılan bu sonuç, Akkaya, Durmuş ve PişkinTunç (2012) tarafından yapılan çalışmanın sonucunda ulaşılan adayların en çok bilgi sahibi oldukları somut materyalin birim küp olduğu sonucu ile farklılaşmaktadır. Buna ek olarak Akkaya, Durmuş ve Pişkin-Tunç (2012) çalışmalarında öğretmen adaylarının en çok bilgi sahibi oldukları somut materyaller arasında "geometrik cisimlerin açılımlarını" bulmaları, yapılan bu çalışma ile örtüşmektedir. Çünkü geometrik cisimlerin açılımları, bilgi sahibi olunan somut materyal olarak, ilk sırada olmasa dahi bu çalışmada da öğretmen adaylarının en çok bilgi sahibi oldukları somut materyaller arasındadır.

Yapılan farklı çalışmalarda da, öğretmen adaylarının en çok bilgi sahibi oldukları farklı somut materyaller rapor edilmiştir. Bakkaloğlu (2007) yaptığı çalışmada farklı iki üniversitede öğrenimlerine devam eden ilköğretim matematik öğretmeni adayları ile çalışmıştır. A üniversitesindeki öğretmen adaylarının en çok 
bilgi sahibi oldukları somut materyal birim küpler iken B üniversitesindeki öğretmen adaylarının onluk taban blokları, birim küpler, geometri tahtası, geometrik cisimler, kesir çubukları ve noktalı kâğıttır. Bu çalışmadan elde dilen veriler incelendiğinde, Bakkaloğlu (2007) çalışması, öğretmen adaylarının en çok bilgi sahibi oldukları somut materyalin saat olması sonucu ile farklılık göstermekte, ama birim küplerin ve geometrik cisimlerin de bilgi sahibi olunan materyaller arasında olması bakımından benzerlik göstermektedir.

$\mathrm{Bu}$ çalışmanın sonuçları incelendiğinde, Akkaya, Durmuş ve Pişkin Tunç’un (2012) ve Bakkaloğlu'nun (2007) yapmış oldukları çalışmalardan farklı olarak öğretmen adaylarının en az bilgi sahibi oldukları somut materyalin cebir karoları olduğu sonucuna ulaşılmıştır. Cebir karolarından sonra en az bilgi sahibi olunan somut materyaller ise çok küplüler takımı, çok kareliler takımı ve şeffaf kesir kartları olmuştur. Akkaya, Durmuş ve Pişkin Tunç'un (2012) çalışmaları incelendiğinde, öğretmen adaylarının en az bilgi sahibi oldukları materyallerin onluk kart ve yüzlük kartlar gibi materyallerin olduğu, Bakkaloğlu'nun (2007) çalışması incelendiğinde ise en az bilinen somut materyalin A üniversitesinde yüzlük tablo ve B üniversitesinde de geometri şeritleri olduğunu belirledikleri görülmektedir. Öğretmen adaylarının en az cebir karoları, çok küplüler takımı, çok kareliler takımı ve şeffaf kesir kartlar ile ilgili bilgiye sahip olmalarının nedeni, daha önce bu materyaller ile hiç karşılaşmamış ve duymamış olmaları olabilir.

$\mathrm{Bu}$ çalışmada ilköğretim matematik öğretmeni adaylarının en çok kullandıkları somut materyalin saat olduğu sonucuna ulaşılmıştır. Saatten sonra en çok kullanılan somut materyal terazi, geometrik cisimlerin açınımları, çizgisiz kâğıt/karton/elişi kâğıdı ve geometrik cisimlerdir. Bunun nedeni ise, adayların bu materyalleri önceki öğrenim hayatlarında veya üniversitede aldıkları derslerde kullanmış olmaları olabilir. Akkaya, Durmuş ve Pişkin Tunç'un (2012) yapmış oldukları çalışmada, bu çalışmadan farklı olarak öğretmen adaylarının en çok kullandıkları somut materyalin birim küpler olduğu sonucuna varmışlardır. Bakkaloğlu'nun (2007) çalışmasında, öğretmen adaylarının en çok kullandıkları materyalin, A üniversitesinde geometrik cisimler, B üniversitesinde noktalı kâğıtları olarak belirtmeleri yapılan bu çalışma ile farklılık göstermektedir. Bakkaloğlu'nun (2007) çalışmasında geometrik cisimler ilk sırada kullanılan somut materyal iken, yapılan bu çalışmada kullanılan materyaller arasında sonlardadır. Buna ek olarak B üniversitesinde öğretmen adaylarının en çok kullandıkları somut materyalin noktalı kâğıt olması da bu çalışma ile farklılık göstermektedir. Bunun yanı sıra bu çalışmadan farklı olarak, Gökmen (2012) çalışmasında hem ilköğretim matematik öğretmenlerinin ve hem de sınıf öğretmenlerinin en çok kullandıkları materyali geometrik cisimler olarak belirlemişlerdir. Buna ek olarak bu çalışmada geometrik cisimlerin, ilk sırada olmasa da, öğretmen adaylarının kullandıkları materyaller arasında olması, çalışmanın Gökmen'nin (2012) çalışması ile benzerlik gösterdiğine işaret eder. Swan ve Marshal (2010) ise yaptıkları çalışmada matematik öğretmenlerinin en çok örüntü bloklarını kullandıklarını ortaya koymuştur. Yapılan bu çalışmada Swan ve Marshal'ın (2010) çalışmasından farklı olarak bu çalışmada örüntü blokları öğretmen adaylarının kullandıkları materyaller arasında düşük kullanma yüzdesine sahiptir.

Çalışmanın sonuçları incelendiğinde öğretmen adaylarının en az kullandıkları somut materyal de cebir karoları olmuştur. Cebir karolarından sonra en az kullanılan somut materyaller ise şeffaf kesir kartları, yüzlük kart ve onluk kartlardır. Bunun sebebi bu materyalleri önceki öğrenim hayatlarında veya üniversitede aldıkları derslerde kullanmamış olmaları olabilir. Gökmen (2012) çalışmasında ilköğretim matematik ögretmenlerinin en az kullandıkları materyali tangram, onluk kart, yüzlük kart olarak belirlerken sınıf öğretmenlerinin cebir karoları olarak belirlemiştir. Gökmen'in (2012) bu çalışmasının sonuçları incelendiğinde en az kullanılan somut materyallerin onluk kart ve yüzlük olması, yapılan bu çalışmanın sonuçları ile tutarlılık göstermektedir. Gökmen'in (2012) çalışmasında sınıf öğretmenlerinin en az kullandıkları somut materyalin cebir karoları olması, yapılan bu çalışmada da ilköğretim matematik öğretmen adaylarının en az kullandıkları somut materyalin cebri karoları olması sonucu ile örtüşmektedir. 
Bakkaloğlu'nun (2007) çalışmasında A üniversitesindeki öğretmen adaylarının en az kullandıkları materyalin yüzlük kart olması, yapılan bu çalışmada da öğretmen adaylarının en az kullandıkları materyaller arasında yüzlük kartın olması ile benzerlik göstermektedir.

Ayrıca bu çalışma kapsamında ulaşılan öğretmen adaylarının somut materyalleri genellikle tanımalarına ve haklarında bilgi sahibi olmalarına rağmen kullanma yüzdeleri daha düşük olduğu sonucu da Akkaya, Durmuş ve Pişkin Tunç (2012) tarafından yapılan çalışmada ulaşılan tangram hakkında öğretmen adaylarının \%82.2'si bilgi sahibi iken bu materyali kullanma oranın \%38.33'e düşmesi sonucu ile tutarlılık göstermektedir. Bu sonuca ulaşılmasının en önemli nedeni ise, okullarda ağırlıklı olarak derslerin teorik yapılması ve çok fazla uygulama yapılmaması olabilir.

Somut materyalleri matematik öğretiminde kullanmaya yönelik öz-yeterlik inançları ölçeğindeki maddelere yönelik verdikleri cevapların ortalamasının yüksek ve olumlu oluşu da, öğretmen adaylarının somut materyalleri matematik öğretiminde kullanma konusunda kendilerini yeterli bulduklarını ve olumlu sonuçlara ulaşacaklarını düşündüklerini göstermektedir. Bunun önemli bir nedeni adayların, üniversitede aldıkları eğitim olabilir. Çünkü çalışmaya katılan öğretmen adayları Öğretim Teknolojileri ve Materyal Tasarımı ve Özel Öğretim Yöntemleri-1 derslerini almışlardır.

Öğretmen adaylarının somut materyalleri matematik öğretiminde kullanmaya yönelik öz-yeterlikleri ile somut materyalleri tanıma ve kullanmaları arasında çok zayıf, negatif yönlü ve anlamlı bir ilişki bulunmuştur. Buna göre öğretmen adaylarının öz-yeterlikleri artarken somut materyalleri tanıma ve kullanma durumları azalmaktadır. $\mathrm{Bu}$ sonuç araştırmadan elde edilen diğer sonuçlar ile tutarlılık göstermektedir. Bazı materyaller katılımcıların az bir kısmı tarafindan tanınmakta ve kullanılmakta olmasına rağmen materyal kullanımına yönelik öz-yeterlikleri yüksektir. Bunun bir nedeni öğretmen adaylarının materyallerin tamamını tanımıyor veya kullanmamış olmalarına rağmen diğer bazı materyalleri farklı derslerden tanıyor ve bu derslerde kullanımını görmüş olmaları olabilir. Bu da öğretmen adaylarında materyal kullanımına yönelik öz-yeterliği artırmış olabilir.

Yapılacak olan çalışmalarda, öğretmen adaylarının somut materyalleri tanımaları ve kullanmaları ile ilgili daha detaylı veri ortaya koyulabilir. Bu süreçte, yapılacak nitel çalışmalarla somut materyalleri nasıl tanıdıkları veya nerede, nasıl kullandıkları açıklanabilir. Buna bağlı olarak da somut materyallerin tanıtımına ve nasıl kullanılacağına dair uygulamalar öğretmenlere hizmet içi kurslar ve çalıştaylar aracılığıyla gösterilebilirken öğretmen adayları için de Öğretim Teknolojileri ve Materyal Tasarımı ile Özel Öğretim Yöntemleri gibi benzer içerikli dersler açılabilir. Ayrıca, bazı materyalleri çok az tanıyan ve kullanan öğretmen adaylarının somut materyalleri kullanma konusunda neden öz-yeterliklerinin yüksek olduğu nitel çalışmalarla ortaya koyulabilir.

\section{Kaynakça}

Akkaya, R., Durmuş, S. ve Pişkin-Tunç, M. (2012). İlköğretim matematik öğretmeni adaylarının somut materyalleri ve sanal öğrenme nesnelerini öğretim süreçleri boyunca kullanabilme durumlarının belirlenmesi. X. Ulusal Fen Bilimleri ve Matematik Eğitimi Kongresi’nde sunulmuş bildiri. Niğde Üniversitesi, Niğde.

Altun, M. (2002). Sayı Doğrusunun Öğretiminde Yeni Bir Yaklaşım. İlköğretim-Online, 1(2), 33-39. 
Bakkaloğlu, E. (2007). Pre-service elementary mathematics teachers' efficacy beliefs about using manipulatives in teaching mathematics (Yayınlanmamış Yüksek Lisans Tezi). Orta Doğu Teknik Üniversitesi, Ankara.

Balcı, A. (2001). Sosyal Bilimlerde Araştırma Yöntem, Teknik ve İlkeler. Ankara: Pegema Yayıncılık.

Bozkurt, A. ve Polat, M. (2011). Sayma Pullarıyla Modellemenin Tam Sayılar Konusunu Öğrenmeye Etkisi Üzerine Öğretmen Görüşleri. Gaziantep Üniversitesi Sosyal Bilimler Dergisi, 10(2), 787 -801.

Brencht, L.J. (2000). The relative effects of cooperative learning, manipulatives and the combination of cooperative learning and manipulative on fourth graders' conceptual knowledge, computation knowledge and problem solving skills in multiplication (Yayınlanmamış Doktora Tezi). Indiana Üniversitesi, Pennsylvania.

Bulut, S. (2004). İlköğretim Programı Yeni Yaklaşımlar Matematik (1-5 Sınıf). Ankara: Milli Eğitim Yayınları.

Bulut, S., Çömlekoğlu, G., Seçil, S.Ö., Yıldırım, H. ve Yıldız, B.T. (2002). Matematik öğretiminde somut materyallerin kullanılması. V. Ulusal Fen Bilimleri ve Matematik Eğitimi Kongresi’nde sunulmuş bildiri. Orta Doğu Teknik Üniversitesi, Ankara.

Clements, D.H. ve McMillen, S. (1996). Rethinking Concrete Manipulatives. Teaching Children Educational Studies in Mathematics, 47, 175-197.

Fuson, K. C. ve Briars, D. J. (1990). Using A Base-Ten Blocks Learning/Teaching Approach for First and Second Grade Place-Value and Multidigit Addition and Subtraction. Journal for Research in Mathematics Education, 21, 180-206.

Gökmen, A. (2012). İlköğretim matematik ve sınıf öğretmenlerinin matematik eğitiminde materyal (manipülatif) kullanmaya yönelik inançları ile kullanım düzeyleri arasındaki ilişki (Yayınlanmamış Yüksek Lisans Tezi). Necmettin Erbakan Üniversitesi, Konya.

Gürbüz, R. (2007). Olasılık Konusunda Geliştirilen Materyallere Dayalı Öğretime İlişkin Öğretmen ve Öğrenci Görüşleri. Kastamonu Ĕgitim Dergisi, 15(1), 259-270.

Hacıömeroğlu, G., ve Apaydın, S. (2009). Tangram Etkinliği ile Çevre ve Alan Hesabı. Illköğretim Online, $8(2), 1-6$.

Kami, C. ve Lewis, B.A. (1990). Constructivism and First Grade Arithmetics. Arithmetic Teacher, 38(1), 3435.

Karasar, N. (2009). Bilimsel Araştırma Yöntemi (20. Baskı). Ankara: Nobel Yayın Dağıtım.

Kelly, A.C. (2006). Using Manipulatives in Mathematical Problem Solving: A Performance-Based Analysis. The Montana Mathematics Enthuasiast, 3(2), 184-193.

Kıyıcı, G., Erdoğmuş, E. ve Sevinç, Ö.S. (2007). Sınıf Ortamında Materyal Kullanımının Eğitim-Öğretime Katkısı İle İlgili Öğretmen Adaylarının Görüşleri. The 7th International Educational Technology Conference sunulmuş bildiri. Near East University, North Cyprus. 
Milli Eğitim Bakanlığı (2013). Ortaokul Matematik Dersi (5, 6, 7 ve 8 Sinıflar) Öğretim Programı. Ankara, Talim ve Terbiye Kurulu Başkanlığı.

Moyer, P.S. (2001). Are We Having Fun Yet? How Teachers Use Manipulatives To Teach Mathematics. Educational Studies in Mathematics, 47(2),175-197.

National Council of Teachers of Mathematics. (2000). Principles and Standards for School Mathematics. Reston, VA: NCTM. Mathematics, 2(85), 270-279.

Özdemir, İ.E.Y. (2008). Sınıf Öğretmeni Adaylarının Matematik Öğretiminde Materyal Kullanımına İlişkin Bilişsel Becerileri. Hacettepe Üniversitesi Eğitim Fakültesi Dergisi, 35, 362-373.

Skemp, R. R. (1987). The Psychology of Learning Mathematics, NJ: Lawrence Erlbaum, Hillsdale.

Swan, P. ve Marshall, L. (2010). Revisiting Mathematics Manipulative Materials. Australian Primary Mathematics Classroom, 15(2), 13-20.

Thompson, P.W. (1994). Concrete Materials and Teaching for Mathematical Understanding. Arithmetic Teacher, 41(9), 556-558.

Ünal, Z.A. ve İpek, A.S. (2009). Gerçekçi Matematik Eğitiminin İlköğretim 7.Sınıf Öğrencilerinin Tam Sayılarla Çarpma Konusundaki Başarılarına Etkisi. Eğitim ve Bilim Dergisi, 34(152), 60-70.

Van de Walle, J. A. (2007). Elementary and Middle School Mathematics: Teaching Developmentally (6th ed.). Boston: MA: Pearson /Allyn and Bacon.

Williams, C.K. ve Kamii, C. (1986). How Do Children Learn By Handling Objects? Young Children, 42(1) $23-46$.

Yolcu, B. ve Kurtuluş, A. (2010). 6. Sınıf Öğrencilerinin Uzamsal Görselleştirme Yeteneklerini Geliştirme Üzerine Bir Çalışma. Illköğretim Online, 9(1), 256-274.

Yalın, H. İ. (1997). Ĕgitim Teknolojisi Öğretim Tasarımı. Ankara: Pegem Yayınevi.

\section{Extended Abstract}

The aim of the study is to reveal the level of awareness pre-service mathematics teachers have about the concrete materials which can be used for mathematics education, and the level of utilization of such materials through the learning process. Furthermore the study seeks to assess the self-efficacy of the preservice teachers regarding the use of such concrete materials. This will help enable uncover any potential relationship between the pre-service teachers' level of acquaintance with and use of the concrete materials and their self-efficacy levels. For this purpose, the study applied the survey model. The study was implemented with 83 pre-service elementary mathematics teachers being trained at the Faculty of Education at a state university in Eastern Black Sea Region of Turkey. A total of 88 pre-service teachers enrolled in the third year of the teacher training program took part in the study. However, data obtained from 5 pre-service teachers were not included in the analysis, as such inputs were incomplete. The data was gathered in the beginning of spring semester of the academic year 2013-2014, as part of the course "Special Education Techniques 2". 
In order to assess the self-efficacy of pre-service teachers regarding the use of concrete materials, the "SelfEfficacy Scale for the Use of Concrete Materials in Mathematics Education" was applied The scale contains 16 question items, and aims to assess the efficacy of pre-service mathematics teachers regarding the use of concrete materials. It is effectively a Likert scale of five, offering the choices I disagree completely (1), I disagree (2), I am undecided (3), I agree (4), and I agree completely (5). The scale entails two factors: "efficacy (self-efficacy) in the use of materials", and "expectations from material use (expected outcome)". Items $1,2,3,4,8,12$ and 14 in the scale present views voiced in negative.

The study used the information sheet to establish the pre-service elementary mathematics teachers' level of awareness about concrete materials and ability to use such materials in the education process. The form contains two questions. The first one is "Are you acquainted with concrete materials?", while the second question is "Have you used concrete materials in the teaching/education of mathematics?" Yes/No responses are requested for the questions; the responses provided by pre-service elementary mathematics teachers were subjected to frequency (f) and percentage (\%) analysis). The scale has a two-factor structure, and allows the generation of individual scores from each sub-scale, as well as the generation of an overall score. The arithmetic averages were interpreted in accordance with the scale of "1.00-1.80" range representing " Completely disagree ", "1.81-2.60" range representing "Disagree", "2.61-3.40" range representing "Undecided", "3.41-4.20" range representing "Agree", and "4.21-5.00" range representing "Completely agree". Then, correlation analysis was applied to assess the relationship between the pre-service mathematics teachers' self-efficacy regarding the concrete material use, and their awareness of and actual use of concrete materials.

Most of the pre-service teachers who took part in the study were observed to be acquainted with concrete materials. The study revealed that the concrete material the largest number (96.39\%) of the pre-service mathematics teachers have been acquainted with is the clock. It is followed by blank paper/paperboard/construction paper (95.18\%), developments of geometric objects (93.98\%), scales (92.77\%), unit cubes $(92.77 \%)$, and geometric objects $(91.57 \%)$. The concrete material the smallest number $(15.66 \%)$ of the pre-service teachers have been acquainted with is the algebraic tiles. These are followed by multiple-blocks set (20.48\%) multiple-squares set (21.69\%), and transparent fraction cards $(22.89 \%)$.

The concrete material used by the largest number (91.57\%) of pre-service elementary mathematics teachers is the clock. It is followed by scales (89.16\%), developments of geometric objects (86.75\%), blank paper/paperboard/construction paper $(86.75 \%)$, and geometric objects $(86.75 \%)$. The concrete material used by the smallest number $(6.02 \%)$ of pre-service teachers is algebraic tiles. These are followed by transparent fraction cards (12.05\%) hundreds deck (13.25\%), and tens deck (13.25\%).

The concrete material acquaintance and use rates vary among the pre-service elementary mathematics teachers. However, for all concrete materials, the rate of actual use of concrete material is lower than the rate of acquaintance.

The average score for the responses provided by pre-service elementary mathematics teachers for the items on the "Self-Efficacy Scale for the Use of Concrete Materials in Mathematics Education" is 3.72 (Agree). This suggests that pre-service elementary school mathematics teachers have high self-efficacy ratings of the use of concrete materials in mathematics education, as well as positive outlooks regarding the outcomes they will achieve through their use.

The pre-service teachers' responses to the items concerning the self-efficacy factor in the "Self-Efficacy Scale for the Use of Concrete Materials in Mathematics Education" used in the study present an average 
figure of 3.55. This figure is also in the "Agree" range, and indicates that their perceived self-efficacy regarding the use of concrete materials is sufficient. Their self-efficacy assessments are highest in terms of the ability to answer the students' questions concerning concrete materials. In addition, they believe that the use of materials in mathematics education would substantially contribute to the students' success.

Furthermore, a very weak, negative yet significant relationship was observed between the pre-service elementary school mathematics teachers' levels of self-efficacy in terms of use of concrete materials in mathematics education and their acquaintance with concrete materials. In the same vein, a very weak, negative yet significant relationship was observed between the pre-service elementary mathematics teachers' levels of self-efficacy in terms of use of concrete materials in mathematics education and their use of concrete materials.

Even though pre-service teachers had usually been acquainted with and knowledgeable about concrete materials, the rate of actual use was lower. This finding is consistent with other studies. The single-most important reason of this could be found in the domination of theoretical contents in the courses, leading to a shortcoming on the applied front.

The average score for the responses provided by pre-service teachers for the items on the "Self-Efficacy Scale for the Use of Concrete Materials in Mathematics Education" reveals a general agreement with the items. This suggests that pre-service elementary mathematics teachers consider themselves to be efficient in terms of the use of concrete materials in mathematics education, and believe that they will achieve positive results through such use. This findings of the study are consistent with other studies. Probably the education provided at the university may lie at the heart of the explanation for this case. For the pre-service teachers who took part in the study had already taken the Instructional Technologies and Material Design course.

The self-efficacy assessments of pre-service teachers, in terms of the use of concrete materials in mathematics education also suggest that they deem themselves to be sufficient in this context. Furthermore, significant relationships were observed between their self-efficacy assessments regarding the use of concrete materials in mathematics education, and the acquaintance with and use of concrete materials. Even though some of these materials are recognized and used only by a smaller number of the participants, the reported self-efficacy regarding material use is high.

Future studies may provide more detailed data on the pre-service teachers' level of acquaintance with and use of concrete materials. The qualitative studies to be carried out in this perspective can help understand how they get to know the concrete materials, and where and how they use such materials. The subsequent outcome of the studies would be to offer on-the-job training courses and workshops for the teachers to improve their skills on the presentation and use of concrete materials, not to mention potential courses to be developed as part of teacher training programs at the universities. Moreover, future qualitative studies may investigate why pre-service teachers who have only a tenuous grasp of and make less use of certain materials still have high self-efficacy assessments. 